\title{
Bureaucratic Reform Of Human Resources In South Tangerang City
}

\author{
Haniah Hanafie \\ Departement of Political Science, Faculty of Social and Political Sciences, \\ Syarif Hidayatullah State Islamic University Jakarta \\ Email: haniah.hanafie@uinjkt.ac.id
}

\begin{abstract}
In 2010, the government of Indonesia launched the Grand Design of Bureaucratic Reform (GDRB) as a reference of government agencies and local governments to implement bureaucratic reforms. There are nine areas of change proclaimed in the GDRB, and one of them is in the field of human resources (HR).

The focus of this research is bureaucratic reform in the field of human resources in South Tangerang City. It is a qualitative research approach supported by observation data, interview, and document review. The data analysis applied in this study is descriptive using data analysis procedure proposed by McNabb (2002: 297) and supported by the theory of Bureaucracy Reform, Human Resources and Effective governance (Callahan, 2007).

The results showed that the Bureaucratic Reform of Human Resources in South Tangerang City had not been run optimally because we still encounter several things, namely, 1) There is still KKN (Collusion, Corruption, and Nepotism) in the recruitment process of employees. 2) The competence of recruited employees is not appropriate. 3) Incompetent staff placement. 4) The number of volunteer worker exceeds the number of permanent employees, or in Bahasa Indonesia called as Pegawai Negeri Sipil (PNS).
\end{abstract}

Keywords - Bureaucratic Reform, Human Resources, and Effective governance.

\section{INTRODUCTION}

Human Resources (HR) is an essential factor in building the governance. $\mathrm{HR}$ is the most valuable organizational resource [1]: the organization's most valuable resources are its staffs. The staff here is an essential human resources organization. Organizations without staffs will not run because the staffs are those who do the task, coordinate and organize input into output.

Malthis and Jackson (2001) [2] explain that human resource development and management are given considerable attention to reform for efficiency and effectiveness in government bureaucracy. Human Resource Development prepares organizations to face the challenges ahead. Malaysia and Singapore have implemented it and succeeded. It is used as a critical pillar of reform as it mentioned:

Recent success stories in human resource development are found in Malaysia and Singapore, where human resource management-a key pillar of reform efforts in both countries-was designed and implemented to meet the needs of the changing role of the state [3]
The importance of human resources in the organization as Robbins et al. (1986) [4] said that the leadership forgets that the failure of an organization happens because the quality of human resources that is not guaranteed.

If an organization tries to achieve its goals, it needs inputs like financial resources (such as money and credit), physical resources (such as building and equipment) and people. Too often, a manager forgets the vital role of the third factor (the people variable) to achieve the success of an organization. Many managers have failed because they have taken their human resources for granted.

Therefore, in 2010, the central government issued a policy of Grand Design of Bureaucratic Reform (GDRB) for all ministries and institutions $(\mathrm{K} /)$ as well as local government. In 2011-2014, it was expected that the central and regional governments would have the commitment and strength to implement bureaucracy reform and by 2025, professional and high integrity government bureaucracy can be actualized (GDRB, 2010) [5].

One of the areas of bureaucracy reform is human resources (HR). Therefore, it is significant to see the bureaucratic reform of the human resources field in South Tangerang City (Tangsel).

\section{THEORETICAL REVIEW}

\section{A. Bureaucratic Reform}

The term Bureaucratic Reform is also known as the Administrative Reform that has been reviewed and implemented in various countries. South Korea established it in 1980, Japan had it during the 1980s, and in China, the administrative reform was introduced by Deng Xiaoping in 1982. Iran also follows the same movement after the fall of Shah Reza Pallevi in 1989.

In Indonesia, Eko Prasojo introduced the term of Bureaucracy Reform (2009) [6] remembering the government's incapacity after political reform in 1999 to change the structure, norms, values, and regulations in the service-oriented and welfare-oriented bureaucracy that failed to meet the aspirations and needs of society [7].

According to Miftah Thoha [8], bureaucracy reform is interpreted as a significant change in the paradigm and governance of Indonesia [9]. Major changes are meant to transform or form effective and efficient government organizations in carrying out duties and functions [10]. 


\section{B. Reform of the HR}

\section{Recruitment}

One way to recruit is by using the merit system, which is considered as a regular and fair process, employment, payment, development, promotion and rotation, discipline and retirement by ability and performance [11].

Hardjapamekas (2002) in Rewansyah (2011) [12] suggests three points to be considered in human resource recruitment. The first one is the main criteria for hiring that at least resulting in integrated human resources, credibility, and capability. The second one is about the base of recruitment, in which the recruitment implementation is should allow career mobility, transition, and broad base of recruitment. The last one appoints that the recruitment process should refer to the main criteria, namely fair, equal opportunity and transparent.

\section{Selection}

Selection of employees to is required get the needs of an organization. It is necessary to analyze the work systematically or called as a workload analysis (ABK) to obtain a compatibility between the recruitment results and the real needs.

The purpose of selection is to obtain human resources which have required competence for the position.

Therefore, an objective standard mechanism / procedure is usually required in the selection of employees. The following are the common selection process: written documents submission (e.g., cover letter), TPA, Personality Test, Psychological test, drug test, honesty test, handwriting test and the main assessment and interview [13].

Selection is made to build human resources that have integrity [14]. Therefore, three things must be considered, namely, first, the selection is based on the assessment of technical competence required and behavior based interview. Second, integrity serves as a core value. Third, integrity serves as an absolute criterion for employee development and promotion.

\section{Training}

Training is an effort to increase the capacity of human resources conducted by agencies in both private organization and government. The increasing capacity of local government human resources has an essential function in staffing to improve organizational performance.

To increase the capacity of human resources in the narrow sense can be done through education and training (Diklat). Meanwhile, in the broader sense, every organization tries to make civil servants becoming more competent in every work completion [15]. Therefore, some policies need to be considered by the Ministry / Institution / Local Government, namely: 1). An objective performance appraisal system. 2). Civil servants recruitment in structural positions that is based on competence. 3 ). Education and training (Diklat) that can support the declining of competence.

\section{Career (Promotion)}

Career or promotion of position is the placement of a person in a particular structural position and adjusted to the needs of the organization. Therefore, a well-established plan must be made to obtain the right person in the right place. Promotion can be done by the organization using two criteria, namely job performance and seniority [16].

Job performance as the basis of promotion must use performance evaluation in the current position. It is not based on the favor or likes and dislike and therefore, maturity must be considered as the potential of the officials.

The development of information system management is necessary to determine the placement of a person's position. Optimization of job analysis (ANJAB) and workload (ABK) must be realized so that it can be known which position is needed and correctly given to the right person.

Seniority-based promotion (experienced and long service) has a weakness because the work period is not necessarily able to assume new responsibilities. Officials' promotion is done openly to begin the bureaucratic reform. The transparent promotional system gives equal opportunity to all elected officials [17].

\section{Payroll}

The level of welfare of civil servants significantly affects their performance and behavior as there is sometimes an imbalance state between the needs of the salary [18]. The income structure of a civil servant is much larger than the actual salary. The actual salary is only about $20-30 \%$, but some project benefits and honors often increase a person's income. Civil servant income is not transparent, so the actual salary is unknown. Thus, the practice of gratuities and bribery tend to happen frequently in the administration.

The payroll system is not based on a performance system and, therefore, the salary is the same for diligent and unskilled employees, [19]. Thus, the payroll system as one associated with HR reform should be changed. The payroll system must be paid according to the performance measurement and the additional pay received should be trimmed. Therefore, performance measurement assessments must also be entirely fair and transparent.

Payroll system should receive attention because it is part of the welfare that goes in line and affects the duties, responsibilities, authorities and risks and performance of employees [20].

\section{METHOD}

\section{A. Research Approach and Data Analysis}

The qualitative approach is used in this research with descriptive analysis technique. The procedure of data analysis [21], consists of 1) Organize the data, 2) Generate categories, themes, and patterns, 3) Code the data, 4) Apply the ideas, themes, and categories, 5) Search for the alternative explanation, 6) Write and present the report. 


\section{B. Data Processing}

Source of data comes from 1) informants (resource persons) are selected by purposive sampling, 2) events and 3) written document. Data collection is done through interviews with some officials of Tangsel City Government, observation, and review of documents related to Bureaucratic Reform of Human Resources.

\section{RESULT AND DISCUSSION}

It will cover the explanation of bureaucracy reform in the field of human resources (HR) related to recruitment and placement, payroll, working conditions, training, and performance.

\section{A. Recruitment and Placement}

Based on the results of interviews, the appointment of employees in Tangsel City is made through a careful selection. The practice of KKN (Collusion, Corruption, and Nepotism) still occurred so that the placement does not pay attention to the quality and qualification of competence.

Collusion happens due to repayment of the successful teams as it takes place in the recruitment and placement of employees. It is often influenced by politicians, especially the recruitment of employees with the status of volunteer worker(TKS) so that it exceeds the number of State Civil Servants (PNS). From the data collected, there are eight Local Government Units (SKPD) that have 843 TKS. Meanwhile, the state civil servants (PNS) comprise of 372 people, in which the number of TKS is $226 \%$ more than State Civil Servants.

Corruption occurs during bribery in appointments and placements in a certain position. It shows the moral hazard that benefits specific groups, thus eliminating the side of fairness and accountability.

Law no. 431999 about Management of State Civil Servants in article 1 appoints that State Civil Servant Management is the whole effort to improve efficiency, effectiveness, and degree of professionalism of the implementation of duties, functions, and employment obligation. Thus, efficiency and effectiveness will not be achieved if employee appointments are unprofessional, not transparent and not objective.

In the placement of employees, especially TKS, Tangsel City Government did not pay attention to the problem of competence that made many teachers occupy the structural position. From eight SKPD studied, there are 24 people that have inconsistent matters (incompetent) with the position. There was a possibility to make this number bigger if the government of Tangsel City was not transparent.

The city government of Tangsel should implement the merit system principle that private appointments, promotions, and other personnel actions are performed by the employee's ability and performance [22].

In a modern state, a merit system in modern government is a staffing system in which comparisons of achievement and competence determine the selection of individuals and careers in employment. It is necessary to look for the elements in the merit system to facilitate it.

The problem of recruitment with fair use of a merit system is an external force that encourages the absence of political intervention. It is due to the bureaucracy in Indonesia that has not been separated from politics [23], or there is political control over bureaucracy [24].

\section{B. Training}

The data obtained show that education and training were conducted internally for six times and thirteen times participating in other areas (external) in 2010-2013. In 2012, the practice was held six times, three times internally and three times externally

It seems that DIKLAT is not yet optimal in implementing education and training for employees, primarily the Technical and Functional training. It should be done as Bernardin and Russell (1998) stated [25]:

The training to bring about specific changes in attitudes, skills, and knowledge. To make it become effective, it should include an exploration of experiences. Therefore, training should be a well-planned and designed organizational activity in response to identified needs.

The optimization of education and training function will improve the performance of employees to become better. On the contrary, the performance of employees will be low if it does not function optimally. Diklat is needed to improve the capacity and performance of employees.

According to Naibaho (2011) [26], capacity building of human resources in the narrow sense is done through education and training (Diklat) Meanwhile, in the broader sense, every organization tries to make civil servants becoming more competent in every work completion.

\section{Working Conditions}

Working conditions are the means and infrastructure that affect the working atmosphere of employees. Working conditions in the South Tangerang City Government is not very conducive. It can be seen from the location of office that is not yet integrated, the form of the office and the spacious room.

There are 11 splitted location points, namely: in Setu Sub-district, Serpong (6 SKPD Offices); Witana Hardja (3 SKPD Offices); Complex Pamulang II (formerly 2 SKPD Office, but currently only 1 SKPD Office); Viktor Area (1 SKPD Office); Jalan Raya Siliwangi (2 SKPD Offices); Jl. Pelayangan Hill, Cilenggang (1 SKPD Office); Jl. Raya Serpong (1 SKPD Office); Jl. Hero of the Thousand (4 SKPD Offices); BSD (4 SKPD Offices); Cilenggang Area (1 SKPD Office); and Area of Rawa Buntu (1 SKPD Office). The dispersal of buildings in eleven point locations becomes a barrier to service regarding communication, time, budget and energy. 
The location is less strategic that make it difficult for people to access. The nameplate as an information guide is not clear, so people mistakenly go to the intended location. BP2T is much in demand by the public to open a business. However, its location is not strategic. It cannot be seen from the highway, and even the signboard is not clear.

Tangsel City Government office building is not as impressive as the Office of Youth and Sports, Regional Library Office and Regional Archives Office Shaped House (RUKO). The Office of Kesbangpolinmas is resembling the residential houses, and the offices are rented. The position of the Office of Youth and Sports is near the shophouses and offices of the Badan Kesbangpolinmas are in residential villages, making it difficult to distinguish between the office and the house.

The area of office space is not conducive that becomes an obstacle to the implementation of employee duties. The average room space of each SKPD is very small. Consequently, it is not free to move and the air circulation is also lacking. The small room is located at the Regional Secretariat Office located in the Serpong area, the Office of Youth and Sports, Cilenggang, Regional Library Office, Regional Archive Office in Pamulang, BLHD in Serpong and Kesbangpolinmas Agency Office, Cilenggang.

The area of each sub-section on Sekda office is only 2.5 Meters times 3 meters, which is similar to rooms for rent. This spacious room contains only two tables and two chairs with two filing cabinets. To put the chair for guests is somewhat difficult because it is very narrow. Meanwhile, employees with the status of TKS do not get an allotment of tables and chairs.

\section{Performance}

LAKIP should be used as a guide to measure the performance, but it is difficult to access. Therefore, there are two indicators to measure the human resource performance of Tangsel City Government in the context of Bureaucracy Reform, namely quality, and timeliness.

Quality is the result/achievement achieved by an SKPD. There are two awards achieved by South Tangerang City Government, namely ADIPURA achieved by South Tangerang City. It was the successes shown by the Regional Environment Agency (BLHD) in 2013. At the same time, the government also received the WTP predicated in the field of finance during the year of 2011.

The development of education has been done from elementary, junior and senior high/vocational school for public and private schools as well as a scholarship for excellent students. Concerning the field of health, it has been built Regional General Hospital (RSUD) and free Puskesmas, as well as developing and improving the infrastructure and facilities in the form of public roads, drainage, and environmental road improvements.
The development of education, health, and infrastructure is a mandatory program that must be implemented by the Tangsel City Government. Therefore, according to the researchers, all of them are not an achievement. Although they are success and development has been doing, the general administrative services are still slow and moral hazard still occurs.

Regarding timeliness, the City Government of Tangsel has not been able to show its performance well, because each SKPD-SKPD does not have SOP, ANJAB, and ABK. In the context of bureaucratic reform, the making of SOPs is necessary for community service standards. While ANJAB and ABK can be used as guidance in the appointment and placement of employees, so the merit system can be realized well.

The development of the State Apparatus has a vital role in creating an advanced and independent Indonesian human being, to be able to compete in the era of globalization [27]. The existence of decentralization policy does not mean that local government is not in a problem. There are a lot of issues to be solved. Therefore, the local governments are necessitated to demonstrate its performance. To fulfill the performance demanded, local government needs to improve the quality of apparatus resources comprising [28]: 1) Reorganizing the Resource Apparatus, 2) Optimizing analysis of the work systematically, comprehensively and consistently, 3) Optimizing the development of Apparatus Resources. 4) Rationalization of the Apparatus

\section{CONCLUSION}

A. Conclusion

1) A merit system has not been implemented in the recruitment of employees in South Tangerang City, as KKN still occurred frequently.

2) The placement of employees has not been based on the competencies required.

3) Immoral action is still happening

4) The technical and Functional Training for employees has not been optimally implemented that consequently affect their performance.

5) The working conditions are not conducive that it cannot provide services perfectly.

\section{B. Recommendations}

1) ANJAB and ABK must be created and realized.

2) Competence should be the basis of selection and promotion

3) The enforcement of rules/laws should be done clearly and decisively.

4) Performance should be a measure in the payroll system.

5) Environment needs to be considered in order to improve employees' performance 


\section{References}

[1] Turner, Mark dan David Hulme. 1997. Governance, Administration \& Development: Making the State Work. USA: Kumarian Press Inc. p.116.

[2] Malthis Robert and J.H Jackson. 2001. Human Resources Management, Jakarta: Salemba Empat, p. 13. .

[3] United Nations. 2007. Governance for the Millennium Development Goals: Core Issues and Good Practices , p 49.

[4] Robbins and Peter S. Low, Mark P. Mourell. 1986. Human Resouces Planning. Prentice Hall Australia, p 107.

[5] Attachment to PP. 81 of 2010 on the Grand Design of Bureaucracy Reform Indonesia 2010-2025. KemenPAN and RB of the Republic of Indonesia.

[6] Prasojo. Eko. 2009. Second Reform: Continuing the Relay Reform. Jakarta: Salemb Humanika, p. 62.

[7] Prasojo. Eko. 2009. Second Reform: Continuing the relay Reform. Jakarta. Salemba Humanika, p 62

[8] Thoha, Miftah. 2010. Contemporary Public Administration Science. Third Print. Jakarta: Prenanda Media Group

[9] PERMenPAN, No. 15 / M.PAN / 7 Year 2008.

[10] Rewansyah, Asmawi. 2009. Bureaucratic Reform in the Framework of Good Governance. No Publisher Name. P 119.

[11] Woodrod, 2000: 14.

[12] Rewansyah, Asmawi. 2009. Bureaucratic Reform in the Framework of Good Governance. No Publisher Name. P 114.

[13] Rivai, Veizhal. 2004. Human Resource Management Company. Jakarta: Murai kencana, p 172.

[14] Sumardi. 2011. "Apparatus Resources as Main Actors of Bureaucratic Reform" in the Journal of Administrative Reform. Issue 1. Year, p 69.

[15] Naibaho, Ramli. 2011. "Building Human Resources Apparatus Integrated, Neutral, Competent, Capable, Professional, High Performing and Prosperous" in the Journal of Administrative Reform. Issue 1. Year I. p. 65

[16] Rewansyah, Asmawi. 2009. Bureaucratic Reform in the Framework of Good Governance. No Publisher Name. P 117.

[17] Public Service Magazine, XLI Edition, Year VIII, 2012, p 16.

[18] Prasojo. Eko. 2009. Second Reform: Continuing the Relay Reform. Jakarta: Salemba Humanika, p. 85

[19] Prasojo. Eko. 2009. Second Reform: Continuing the Relay Reform . Jakarta: Salemba Humanika, p. 86.

[20] Naibaho, Ramli. 2011. "Building Human Resources Apparatus Integrated, Neutral, Competent, Capable, Professional, High Performing and Prosperous" in the Journal of Administrative Reform. Issue 1. Year I. p. 63

[21] McNabb, David E. 2002. Research Methods in Public Administration and Nonprofit Management: Quantitative and Qualitative Approaches.USA: M.E. Sharpe

[22] Negro and Negro in Woodrod, 2000, p. 15.

[23] Prasojo. Eko. 2009. Second Reform: Continuing the Relay Reform. Jakarta: Salemba Humanika, p. 85.

[24] Frederickson, H. George.and Kevin B. Smith. 2003. The Public Administration Theory Primer. Colorado: Westview Press.

[25] Bernardin dan Russell (1998:172) in http://id.wikipedia.org/wiki/pelatihan, downloaded on June 18, 2013.

[26] Naibaho, Ramli. 2011. Building Human Resources Apparatus Integrated, Neutral, Competent, Capable, Professional, High Performing and Prosperous" in the Journal of Administrative Reform. Edition 1. Year I. p. 65.
[27] Naibaho, Ramli. 2011. Building Human Resources Apparatus Integrated, Neutral, Competent, Capable, Professional, High Performing and Prosperous" in the Journal of Administrative Reform. Edition 1. Year I. p. 56

[28] Satibi, Iwan. 2011. "Optimizing Performance Improvement of Regional Devices in Perspective of Quality of Apparatus Resources". Journal of State Administration Science PUBLICA, Vol. 1. No. 1, p. 76-81. 